\title{
KEPATUHAN MENJALANKAN MANAJEMEN DIRI PADA PASIEN HEMODIALISIS
}

\author{
Sri Hartati Pratiwi*, Eka Afrima Sari, Titis Kurniawan \\ Fakultas Keperawatan, Universitas Padjadjaran \\ *sri.hartati.pratiwi@unpad.ac.id
}

\begin{abstract}
Abstrak
Pasien gagal ginjal kronik harus menjalankan manjemen diri diantaranya hemodialisis, pengobatan, pembatasan cairan dan diet. Angka morbiditas dan mortalitas pada pasien hemodialisis akan meningkat apabila tidak menjalankan manajemen diri dengan baik. Penelitian ini dilakukan untuk mengidentifikasi kepatuhan pasien hemodialisis dalam menjalankan manajemen diri. Penelitian ini merupakan penelitian deskriptif yang dilakukan kepada pasien di Unit Hemodialisis di salah satu rumah sakit terbesar di Jawa Barat. Teknik pengambilan sampel yang digunakan adalah consecutive sampling dengan jumlah responden 129 orang. Teknik pengumpulan data dilakukan dengan kuesioner kepatuhan menjalankan manajemen diri pada pasien hemodialisis diadaptasi dari kuesioner End Stage Renal Disease Adherence. Data dianalisis dengan menggunakan distribusi frekuensi berupa frekuensi, persentase, dan mean. Sebagian besar responden tidak patuh dalam menjalankan manajemen diri 92 orang dan patuh sebanyak 28,7\% yaitu 37 orang. Kepatuhan pasien dalam menjalankan hemodialisis sesuai jadwal sudah baik dengan rata-rata skor 271,3. Kepatuhan pasien hemodialisis masih kurang dalam membatasi asupan cairan dengan rata-rata skor 120, makanan dengan rata-rata skor 147, dan pengobatan dengan rata-rata skor 133). Tenaga kesehatan diharapkan dapat memberikan dukungan kepada pasien dengan memberikan edukasi, konseling dan promosi kesehatan dengan menggunakan berbagai media termasuk media sosial terkait pentingnya pengontrolan cairan dan makanan.
\end{abstract}

Kata kunci: Hemodialisis, Kepatuhan manajemen diri

\begin{abstract}
Compliance with running self-management on hemodializing patients Patients with chronic kidney failure must carry out self-management including hemodialysis, treatment, fluid and dietary restrictions. The morbidity and mortality rates in hemodialysis patients will increase if they do not carry out self-management properly. This study was conducted to identify the compliance of hemodialysis patients in carrying out self-management. This research was a descriptive study conducted on patients at the Hemodialysis Unit in one of the largest hospitals in West Java. The sampling technique used was consecutive sampling with the number of respondents 129 people. Data collection techniques carried out by compliance questionnaire method of running self management in hemodialysis patients adapted from the End Stage Renal Disease Adherence questionnaire. Data were analyzed using frequency distributions in the form of frequency, percentage, and mean. Most of the respondents were not obedient in carrying out self-management as many as $71.3 \%, 92$ people and obedient as many as 28.7\%, 37 people. Patient compliance in conducting hemodialysis schedule has been good with mean 271.3. Compliance with hemodialysis patients was still lacking in limiting fluid intake with mean 120, food with mean 147, and treatment with mean 133. Health workers are expected to be able to provide support to patients by providing education, counseling and health promotion by using various media including social media related to the importance of controlling fluids and food that must be carried out by hemodialysis patients.
\end{abstract}

Keywords: Adherance, Hemodialysis, Self-Management

\section{Pendahuluan}

Gagal ginjal merupakan salah satu penyakit kronik yang semakin banyak terjadi di dunia. Angka kejadian gagal ginjal kronik di Amerika Serikat tahun 2012 mencapai 363 persatujuta orang pertahun dan meningkat pada tahun 2013 menjadi 117.162 kasus (Usrds, 2017).
Indonesia merupakan salah satu negara dengan kasus gagal ginjal yang terus meningkat. Angka kejadian gagal ginjal kronik di Indonesia pada tahun 2013 mencapai 0,2\% (Ministry of Health Republic of Indonesia [MOHRI], 2017).

Gagal ginjal adalah suatu penyakit yang disebabkan oleh kerusakan fungsi 
ginjal yang ditandai dengan penurunan Glomerolus Filtration Rate (GFR) yang kurang dari $60 \%$ dan disertai dengan adanya peningkatan kadar urea dan kreatinin serum. Ginjal berfungsi dalam reabsorpsi dan ekskresi berbagai cairan dan zat sisa metabolisme, pengaturan asam basa, pembentukan hormon eritropoetin yang berperan dalam pembentukan sel darah merah, mengatur tekanan darah dan lain-lain. Pasien gagal ginjal akan mengalami berbagai gejala yang disebabkan oleh gagalnya fungsi ginjal sehingga terjadi penumpukan cairan, kreatinin serum, anemia, peningkatan tekanan darah, dan lain-lain. Gejala yang sering dirasakan pasien gagal ginjal diantaranya adalah disuria, anuria, edema, sesak nafas, asites, anemia, pruritus dan lain-lain. Untuk mengatasi gejala tersebut, pasien gagal ginjal harus melakukan terapi pengganti ginjal (Smeltzer and Bare, 2010).

Terapi pengganti ginjal yang paling banyak di Indonesia adalah hemodialisis. Pasien gagal ginjal yang menjalani hemodialisis di Indonesia pada tahun 2015 mencapai 1.243 orang (Kementrian Kesehatan RI, 2017). Hemodialisis merupakan salah satu terapi pengganti ginjal dengan menggunakan perbedaan tekanan antara kompartemen darah dengan cairan dialisat melalui membran semipermeabel sebagai ginjal buatan. Melalui proses hemodialisis, zat sisa metabolisme dan cairan yang menumpuk pada tubuh pasien gagal ginjal kronik dapat dikeluarkan sehingga gejala yang dirasakan akan berkurang. Walaupun demikian, efek hemodialisis hanya bertahan sementara karena metabolisme tubuh tetap berjalan. Seiring dengan metabolisme tubuh, cairan dan sisa metabolisme pada tubuh pasien gagal ginjal akan kembali bertambah. Oleh karena itu, pasien gagal ginjal harus menjalani hemodialisis secara teratur dan menerapkan manajemen diri yang baik (Daugirdas, Blake, \& Ing, 2007).
Pasien hemodialisis harus menjalankan manajemen diri dengan baik untuk meningkatkan kondisi kesehatannya. Manajemen diri merupakan aktivitas dalam kehidupan sehari-hari yang dilakukan untuk memelihara kesehatan dan kesejahteraan dalam jangka waktu yang panjang (Challis et al., 2010). Manajemen diri merupakan salah satu bagian penting dalam pengendalian penyakit kronik. Manajemen diri dilakukan untuk meningkatkan kesejahteraan, memelihara kesehatan, serta stabilitas kondisi fisik dan emosi (Riegel, Jaarsma, Strömberg, Clemmer, \& Chair, 2012). Pasien hemodialisis diharapkan dapat memelihara kondisi kesehatannya dengan membatasi asupan cairan dan natrium, mengontrol makanan, beraktivitas sesuai kemampuan dan mengontrol stress yang dirasakannya. Manajemen diri pada pasien hemodialisis mencakup kepatuhan dalam menjalankan hemodialisis, pengobatan, cairan dan diet (Kim, Fellow, Evangelista, \& Professor, 2010).

Pasien gagal ginjal kronik harus menjalani manajemen diri yang baik dalam pembatasan asupan cairan dan natrium. Pembatasan cairan dan natrium pada pasien hemodialisis dapat mengurangi akibat dari peningkatan volume cairan tubuh, menurunkan tekanan darah dan Interdialitic Weight Gain (IDWG) (Mc Causland, Brunelli A-C Sushrut, \& Waikar, 2013). Ketidakpatuhan pasien hemodialisis dalam menjalankan manajemen cairan dan diet dapat berpengaruh buruk terhadap kondisi kesehatan pasien, diantaranya dapat menyebabkan peningkatan tekanan darah (Marsenic, Anderson, \& Couloures, 2016). Apabila pasien hemodialisis tidak dapat mengontrol asupan cairan dan diet maka akan memperburuk edema, sesak, gatalgatal serta gejala lainnya. Selain itu, ketidakpatuhan pasien hemodialisis dalam menjalankan manjemen diri dapat menimbulkan kerugian secara ekonomi karena pasien harus mengeluarkan biaya perawatan yang lebih besar. Manajemen 
diri yang baik pada pasien hemodialisis dapat meningkatkan kualitas hidupnya (Daugirdas, Blake, \& Ing, 2007). Penelitian ini merupakan penelitian deskriptif kuantitatif untuk mengidentifikasi kepatuhan pasien hemodialisis dalam menjalankan manajemen diri.

\section{Metode}

Penelitian ini merupakan penelitian deskriptif dengan variabel kepatuhan menjalankan manajemen diri pada pasien hemodialisis. Penelitian ini dilakukan pada bulan September 2018 kepada pasien gagal ginjal kronik yang menjalani hemodialisis di RSUP Dr. Hasan Sadikin Bandung. Teknik pengambilan sampel pada penelitian ini adalah consecutive sampling dengan jumlah responden 129 orang. Kriteria inklusi dalam penelitian ini adalah pasien gagal ginjal yang menjalani hemodialisis, serta memiliki tanda-tanda vital yang stabil. Penelitian ini sudah mendapatkan ijin etik dari Komisi Etik Penelitian Universitas Padjadjaran No 591/UN6.KEP/EC/2018.

Tekhnik pengumpulan data dilakukan dengan metode kuesioner atau angket. Instrumen yang digunakan dalam penelitian ini adalah kuesioner kepatuhan menjalankan manajemen diri pada pasien hemodialisis diadaptasi dari kuesioner End Stage Renal Disease Adherence (ESRDAQ) yang dikembangkan oleh (Kim et al., 2010) yang berjumlah 46 item dan terdiri dari 5 bagian diantaranya adalah informasi umum, tindakan hemodialisis, pengobatan, cairan, dan diet.

\section{Hasil}

Data responden dikumpulkan untuk melihat karakteristik responden. Data tersebut terdiri dari usia, pendidikan terakhir, pekerjaan, dan lama menjalani dialisis. Karakteristik responden dalam penelitian ini dapat dilihat pada tabel 1 .

Tabel 1.

Karakteristik Responden $(n=129)$

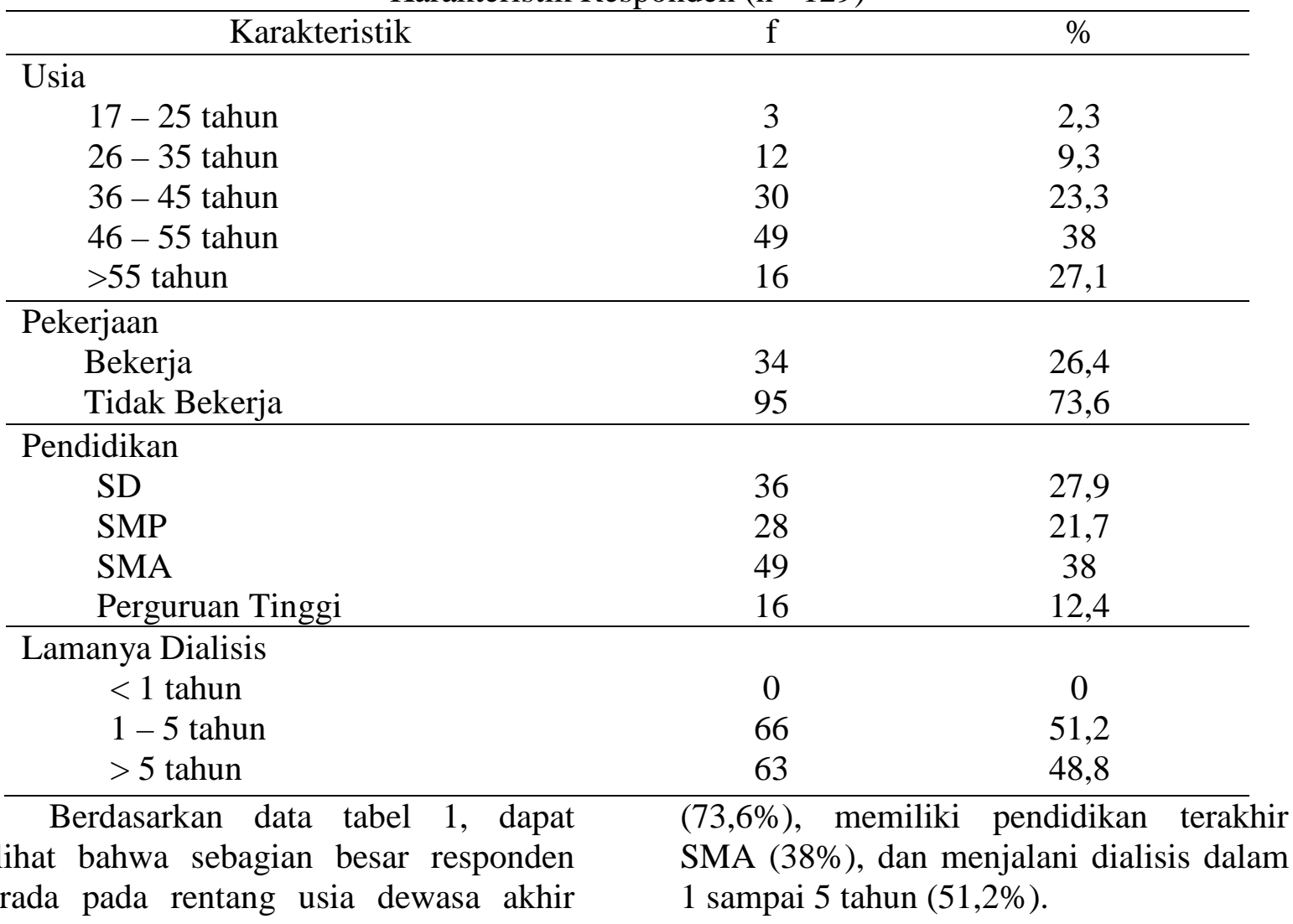
yaitu 46 - 55 tahun (38\%), tidak bekerja 
Jurnal Perawat Indonesia, Volume 3 No 1, Hal 131-138, Agustus 2019 Persatuan Perawat Nasional Indonesia Jawa Tengah

Kepatuhan menjalankan manjemen

tabel 2 berikut ini

diri pada penelitian ini dapat dilihat pada

Tabel 2.

Kepatuhan Pasien Hemodialisis Dalam Menjalankan manajemen diri

\begin{tabular}{lrllr}
\hline \multicolumn{1}{c}{ Kepatuhan } & $\mathrm{f}$ & \multicolumn{1}{c}{$\%$} \\
\hline Patuh & 37 & & 28,7 \\
Tidak Patuh & 92 & & 71,3 \\
\hline Berdasarkan data pada tabel 2, & dalam menjalankan manajemen diri \\
sebagian besar responden tidak patuh & $\begin{array}{l}\text { berdasarkan dimensinya dapat dilihat pada } \\
\text { tabel 3. }\end{array}$
\end{tabular}

sebanyak 92 orang $(71,3 \%)$ dan patuh

sebanyak 37 orang $(28,7 \%)$. Kepatuhan

Tabel 3.

Kepatuhan pasien hemodialisis dalam menjalankan manajemen diri terhadap berbagaitindakan

\begin{tabular}{lcc}
\hline \multicolumn{1}{c}{ Kepatuhan } & Rentang Skor & Mean (SD) \\
\hline Kehadiran HD & $100-300$ & $271,3(60)$ \\
Mempersingkat Episode HD & $0-200$ & $197(11)$ \\
Mempersingkat Durasi HD & $0-100$ & $100(9,9)$ \\
Kepatuhan Dalam Pengobatan & $0-200$ & $133(29)$ \\
Kepatuhan Dalam Pembatasan Cairan & $0-200$ & $120(29)$ \\
Kepatuhan Dalam Pembatasan Diet & $0-200$ & $147(18)$ \\
\hline
\end{tabular}

Berdasarkan tabel 3, kepatuhan pasien dalam menjalankan hemodialisis memiliki skor mean yang tinggi pada rentangnya masing-masing, dalam kehadiran HD $(271,3 \pm 60)$, mempersingkat episode HD (197 \pm 11$)$, mempersingkat durasi HD $(100 \pm 9,9)$. Responden tidak patuh dalam pembatasan diet $(147 \pm 18)$, pengobatan $(133 \pm 29)$, dan pembatasan diet $(147 \pm 18)$.

\section{Pembahasan}

Pasien hemodialisis harus menjalankan berbagai terapi pengobatan diantaranya adalah hemodialisis sesuai jadwal, penggunaan obat-obatan sesuai anjuran, pembatasan asupan cairan dan makanan. Dalam menjalankan pengobatan tersebut, pasien hemodialisis harus melakukan manajemen diri sehingga pengobatan dapat berjalan sesuai dengan harapan dan tujuan pengobatan dapat tercapai. Manajemen diri didefinisikan sebagai kemampuan individu, keluarga atau masyarakat untuk mempromosikan kesehatan, mencegah penyakit, memelihara kesehatan dan koping terhadap penyakit, dan ketidakmampuan dengan atau tanpa dukungan dari tenaga kesehatan. Manajemen diri mencakup promosi kesehatan dan pencegahan serta pengontrolan penyakit, pengobatan diri, memberikan perawatan kepada orang yang memiliki ketergantungan, mencari pertolongan petugas kesehatan dan rehabilitasi termasuk perawatan paliatif (World Health Organization, 2017).

Pasien hemodialisis harus melakukan manajemen diri untuk mempertahankan kondisi kesehatan dan meningkatkan kualitas hidupnya. Manajemen diri yang harus dilakukan pasien hemodialisis diantaranya adalah perawatan fistula, aktivitas, diet, monitoring berat badan dan tekanan darah. Pasien hemodialisis harus mengurangi asupan cairan untuk mengontrol berat badan dan tekanan darah. Selain itu, pasien hemodialisis harus patuh dalam menjalankan hemodilisis dan mengkonsumsi obat-obatan (Daugirdas, Blake, \& Ing, 2007). Berdasarkan hasil penelitian pada tabel 2, sebagian besar responden tidak patuh dalam menjalankan 
manajemen diri yaitu sebanyak 92 orang $(71,3 \%)$ dan patuh sebanyak 37 orang $(28,7 \%)$. Kemampuan pasien hemodialisis dalam menjalankan manajemen diri dipengaruhi oleh berbagai faktor diantaranya adalah pengetahuan, selfefficacy, dukungan sosial dan depresi. Pengetahuan merupakan dasar dalam menentukan suatu perilaku. Pengetahuan pasien mengenai manajemen diri dapat bertambah seiring dengan lamanya pasien menjalani hemodialisis (Rantanen et al., 2008). Sebagian besar responden penelitian ini $(51,2 \%)$ sudah menjalankan hemodialisis selama 1-5 tahun sehingga pasien sudah lama mengetahui manajemen diri yang harus dilakukannya.

Berdasarkan tabel 3, kepatuhan pasien dalam menjalankan hemodialisis sesuai jadwal sudah baik $(x=271,3$ dari skor maksimal 300). Kepatuhan pasien hemodialisis masih kurang dalam membatasi asupan cairan $(\mathrm{x}=120$ dari skor maksimal 200), makanan ( $x=147$ dari skor maksimal 200), dan pengobatan $(\mathrm{x}=133$ dari skor maksimal 200). Hasil penelitian ini sama dengan hasil penelitian serupa di berbagai negara yang menyebutkan bahwa sebagian besar pasien hemodialisis tidak patuh dalam pembatasan cairan dan makanan (Chironda \& Bhengu, 2016).

Pasien hemodialisis kesulitan dalam melakukan pembatasan asupan cairan karena merasakan haus, mulut yang kering, lupa, menyukai minuman, sulit mengukur minuman yang harus diminum. Peningkatan jumlah cairan pada tubuh pasien hemodialisis dapat meningkatkan angka kesakitan dan kematian (Ekinci et al., 2018). Asupan cairan yang banyak dapat menyebabkan penumpukan cairan dalam tubuh pasien karena terganggunya fungi ginjal untuk mensekresikan cairan dan zat sisa metabolisme lain. Kondisi ini akan menyebabkan peningkatan Inter Dialitic Weight Gain (IDWG), edema, sesak, peningkatan tekanan darah bahkan bisa menyebabkan gagal jantung (Daugirdas, Blake, \& Ing, 2007).
Ketidakpatuhan

hemodialisis dalam menjalankan manajemen diri dapat memperburuk kondisinya. Asupan cairan yang berlebih pada pasien hemodalisis dapat mengakibatkan volume cairan dalam tubuhnya berlebih sehingga dapat menimbulkan komplikasi kardiovaskular pada pasien hemodialisis (Kumari Shrestha \& Samydayak, 2016). Terdapat berbagai komplikasi gagal ginjal kronik yang dapat terjadi apabila pasien tidak patuh dalam menjalankan manajemen diri diantaranya adalah sesak, gangguan sindrom uremik yang hebat. Pasien hemodialisis yang tidak patuh dalam menjalankan manajemen diri akan mengalami perburukan kondisi, dan pengobatan yang dijalankan tidak akan efektif. Oleh karena itu, petugas kesehatan diharapkan dapat melakukan berbagai intervensi yang dapat meningkatkan kepatuhan pasien hemodialisis dalam menjalankan manajemen diri.

Berdasarkan hasil penelitian ini, pasien hemodialisis juga belum patuh dalam melakukan pembatasan makanan. Pasien hemodialisis merasakan berbagai kendala dalam pembatasan makanan diantarnya kesulitan untuk mengikuti anjuran diet, tidak menyukai apa yang direkomendasikan, tidak tahu, dan kurangnya dukungan dari lingkungan sekitar (Barriers to Treatment Adherence for Dialysis Patients, 2018). Pasien hemodialisis mengontrol asupan beberapa jenis zat yang ada dalam makanan seperti fosfor, potassium, natrium, dan protein. Pasien hemodialisis sebaiknya membatasi asupan makanan yang banyak mengandung fosfor seperti daging, ikan, susu, keju, coklat. Selain fosfor, pasien hemodialisis harus menghindari asupan makanan tinggi kalium seperti pisang, jus jeruk, kacang, alpukat, tomat, papaya, dan lain-lain. Makanan yang banyak mengandung natrium diantaranya biskuit, sosis, saus dan lain-lain. (The Renal Diet A Guide to Eating Healthier for Hemodialysis Patients, n.d.). 
Makanan yang banyak mengandung fosfor, kalium, dan natrium dapat mengubah tekanan osmotik sehingga cairan dalam tubuh pasien akan lebih banyak tertahan, volume darah meningkat dan dapat menyebabkan peningkatan tekanan darah (Canaud et al., 2019). Asupan protein yang tinggi pada pasien hemodialisis dapat meningkatkan jumlah zat sisa metabolisme protein seperti ureum dan kreatinin dalam tubuh pasien. Kondisi ini dapat menyebabkan kejadian azotemia dimana kadar ureum dan kreatinin serum pasien meningkat. Peningkatan kadar ureum dan kreatinin dalam tubuh pasien dapat menyebabkan iritasi di kulit, dan bagian tubuh yang lain (Smeltzer \& Bare, 2010). Oleh karena itu, pasien hemodialisis diharapkan dapat mengontrol asupan makanan. Tenaga kesehatan khususnya perawat diharapkan dapat membantu pasien dalam menjalankan manajemen diri yang harus dilakukannya. Selain itu, keluarga dan lingkungan sekitar juga diharapkan dapat memberikan dukungan kepada pasien dalam menjalankan manajemen dirinya.

Kepatuhan pasien dalam menjalankan manajemen diri dapat ditingkatkan dengan pemberian edukasi yang menyeluruh dan dilakukan secara terus menerus. Berbagai metode dapat dilakukan dalam pemberian edukasi kepada pasien, diantaranya adalah dengan pemberian edukasi secara ajakan verbal, penggunaan video, buku, dan pemberian informasi melalui sosial media. Pemberian edukasi mencakup self-efficacy pasien atau keyakinan pasien dengan kemampuannya dalam melalukan perbuatan untuk mengurangi gejala yang dapat meningkatkan kondisi kesehatannya (Thoesen Coleman \& Newton, 2005). Selain itu, edukasi dapat dilakukan dengan melibatkan keluarga untuk memberikan dukungan kepada pasien dalam melakukan manajemen diri.

\section{Simpulan}

Pasien gagal ginjal kronik harus menjalankan manajemen diri untuk menjaga kondisi tubuhnya sehingga tetap memiliki hidup yang berkualitas. Berdasarkan hasil penelitian ini, sebagian besar responden tidak patuh dalam menjalankan manajemen diri yaitu sebanyak 92 orang $(71,3 \%)$ dan patuh sebanyak 37 orang (28,7\%). Kepatuhan pasien dalam menjalankan hemodialisis sesuai jadwal sudah baik $(x=271,3$ dari skor maksimal 300). Kepatuhan pasien hemodialisis masih kurang dalam membatasi asupan cairan $(\mathrm{x}=120$ dari skor maksimal 200), makanan ( $\mathrm{x}=147$ dari skor maksimal 200), dan pengobatan $(\mathrm{x}=133$ dari skor maksimal 200).

\section{Daftar Pustaka}

Barriers to Treatment Adherence for Dialysis Patients. (2018). Retrieved from

http://www.kidneyfund.org/assets/pd f/akf-adherence-report.pdf

Canaud, B., Kooman, J., Selby, N. M., Taal, M., Francis, S., Kopperschmidt, P., ... Titze, J. (2019). Sodium and water handling during hemodialysis: new pathophysiologic insights and management approaches for improving outcomes in end-stage kidney disease. Kidney International, 95, 296-309. https://doi.org/10.1016/j.kint.2018.09 .024

Challis, D., Hughes, J., Berzins, K., Reilly, S., Abell, J., \& Stewart, K. (n.d.). Self-care and Case Management in Long-term Conditions: The Effective Management of Critical Interfaces Report for the National Insitute for Health Research Service Delivery and Organisation programme April 2010. Retrieved from https://www.pssru.ac.uk/pub/MCpdfs /SCCMfr.pdf

Chironda, G., \& Bhengu, B. (2016). Contributing Factors to Non- 
Adherence among Chronic Kidney Disease (CKD) Patients: A Systematic Review of Literature. https://doi.org/10.21767/2471299X.1000038

Daugirdas, Blake, and Ing. (2007). Handbook of Dialysis Fourth Edition. USA : Lippincott Williams and Wilkins

Ekinci, C., Karabork, M., Siriopol, D., Dincer, N., Covic, A., \& Kanbay, M. (2018). Effects of Volume Overload and Current Techniques for the Assessment of Fluid Status in Patients with Renal Disease. Depth Review Blood Purif, 46, 34-47. https://doi.org/10.1159/000487702

Kementrian Kesehatan RI. (2017). Penyakit, Situasi Kronis, Ginjal. InfoDATIN. Retrieved from http://www.depkes.go.id/download.p hp?file=download/pusdatin/infodatin /infodatin ginjal 2017.pdf

Kim, Y., Fellow, F.-Cp.-D., Evangelista, L. S., \& Professor, Rna. (2010). Relationship between Illness Perceptions, Treatment Adherence, And Clinical Outcomes in Patients On Maintenance Hemodialysis. Nephrol Nurs J (Vol. 37). Retrieved from

https://www.ncbi.nlm.nih.gov/pmc/ar ticles/PMC3172671/pdf/nihms32119 9.pdf

Kumari Shrestha, B., \& Samydayak, N. (2016). Self Care Knowledge among Chronic Kidney Disease Patients Undergoing Maintenance Hemodialysis. Retrieved from https://pdfs.semanticscholar.org/992a /629f6473226c62768d7f8444b60529 0beb43.pdf

Marsenic, O., Anderson, M., \& Couloures, K. G. (2016). Relationship between Interdialytic Weight Gain and Blood Pressure in Pediatric Patients on Chronic Hemodialysis. BioMed Research International, 2016. https://doi.org/10.1155/2016/597293 0
Mc Causland, F. R., Brunelli A-C Sushrut, S. M., \& Waikar, S. (2013). E-Mail Dialysis Dose and Intradialytic Hypotension: Results from the HEMO Study. https://doi.org/10.1159/000355958

Ministry of Health Republic of Indonesia [MOHRI], 2017. (2017). No Title. InfoDATIN. Retrieved from www.depkes.go.id/download.php?.../ infodatin/infodatin ginjal..

Rantanen, M., Kallio, T., Johansson, K., Salanterä, S., Virtanen, H., \& LeinoKilpi, H. (2008). Knowledge expectations of patients on dialysis treatment. Nephrology Nursing Journal: Journal of the American Nephrology Nurses' Association, 35(3), 249-255; quiz 256. Retrieved from

http://www.ncbi.nlm.nih.gov/pubme d/18649585

Riegel, B., Jaarsma, T., Strömberg, A., Clemmer, E., \& Chair, S. (2012). A Middle-Range Theory of Self-Care of Chronic Illness, 3(35), 194-204. https://doi.org/10.1097/ANS.0b013e $318261 \mathrm{~b} 1 \mathrm{ba}$

Smeltzer, S.O. and Bare, B.G. 2010. Brunner \& Suddart Medical Surgical Nursing. 12th edition. Philadelphia: Lippincott Williams and wilkins.

The Renal Diet A Guide to Eating Healthier for Hemodialysis Patients. (n.d.). Retrieved from https://www.vcuhealth.org/media/file /renal_diet.pdf

Thoesen Coleman, M., \& Newton, K. S. (2005). Supporting Self-management in Patients with Chronic Illness components of Patient education and Self-management education (Vol. 72). Retrieved from http://www.aafp.org/afpsort.xml.Tabl e1www.aafp.org/afp

Usrds. (n.d.). 2017 USRDS Annual Data Report: Executive Summary. Retrieved from https://www.usrds.org/2017/downloa d/2017_Volume_1_CKD_in_the_US 
Jurnal Perawat Indonesia, Volume 3 No 1, Hal 131-138, Agustus 2019 Persatuan Perawat Nasional Indonesia Jawa Tengah

.pdf

World Health Organization. (2017). Self care for health: a handbook for community health workers \& volunteers. 